\title{
School of Visionary Leadership in Developing Characters of Students
}

\author{
Agus Prasetya \\ Department of Education Management \\ Universitas Negeri Surabaya \\ Surabaya, Indonesia \\ agus.18012@mhs.unesa.ac.id
}

\begin{abstract}
The purpose of this research is the formulation of the vision, the stage of establishing a vision by the principal, the approach taken by the principal in implementing visionary leadership in developing the character of students. The method in this study uses qualitative methods, which intends to understand the phenomenon of the necessity, action, overall condition of a research subject. While the type of research is a case study. The results in this study are: 1 ) the formulation of the vision carried out by the principal with the SWOT analysis on the school; 2) the process of shared vision by the principal through stages; 3 ) the application of vision is carried out through polite behavior, smile, greetings, greetings, responsibility, discipline and order, and good cooperation with the business world and the industrial world; 4) approaches in implementing leadership of principals are carried out through spiritual research activities, workshops, application of $5 \mathrm{~S}$ industry culture, core values of schools, and role models for school members; 5) the character of students developed in the leadership of the principal, namely religious, disciplinary and responsibility implemented in the dhuhur and ashar prayer activities in congregation and short letters, and the Person in Charge (PIC).
\end{abstract}

Keywords-visionary leadership; developing characters; educational management

\section{INTRODUCTION}

Schools are educational institutions that become a system, meaning that everything that is in school has an important role that is complementary and related. The system will develop the abilities and character of students who are nurtured by the school to produce output and create competent outlines for the school, society, country, and religion. [1] added that the characteristics of the visionary leader are always learning continuously, service oriented, radiating positive energy, trusting others, living a balanced life, seeing life as an adventure, synergistic, always practicing for renew yourself to be able to achieve achievement. The main key to driving an organizational system is human resources, therefore a school must have good and quality human resources. The main priority is that the planning of educational development programs, as well as the development of the character of participants-educators in schools running optimally, is in the hands of educators and education personnel as well as other Human Resources components in schools. Good and quality human resources are certainly printed from the environment and good management, and good leadership.
A school principal as part of the education staff who is also a leader in an educational institution has an important role in developing the character of students through their leadership skills. [2] they define leadership as the behavior of an individual who leads a group's activities to a goal that they want to achieve together. In leading an educational institution the principal becomes one of the main actors in determining the vision and goals of the school as the future direction of the institution he leads. This is one of the school principals' leadership efforts in developing the character of their students. In this school the character that is so pronounced is that religious formation is applied. As explained by Bill Perkin in his book entitled "Awaken the Leader Within" or arouse leadership in yourself, with the following principles: first, the leader who has vision is a ship builder, not a shipping manager; second, visionary leaders know their basic values and have a vision that states them all; third, the visionary leader knows the purpose of their trip and has a vision that states it; fourth, visionary leaders have a clear and shaking vision. [3] emphasizes the importance of institutionalizing vision by always linking it in decision making, policy formulation, preparation of procedures for implementing program evaluation steps. The implementation of visionary leadership in Health Vocational School Surabaya is one of the uniqueness because this school is located far from the city center and is rarely accessed by public transport, but still has the trust of the community with a superior program of religious character development. The implementation of the principal's visionary leadership develops values for students so that they shape character through habituation-habituation in activities at school.

\section{METHOD}

The approach used in this study is a qualitative approach, a type of case study research. This study intends to find out in depth the visionary leadership of Surabaya Health Vocational School heads in developing the character of students at school. The reason for using a case study is to focus on a case that is uniquely incentive and detailed. Sumner's data in this study are principals, vice principals, student departments, study program heads, subject teachers, students, and graduates. Deputy headmaster of community relations as key informant regarding the 4-year learning system. Data collection is done by using interview, observation, and documentation techniques. Data analysis was carried out before the researcher entered the field, during the field and after completion in the 
field. Data analysis is carried out simultaneously with data collection. In analyzing the data, the researcher reduced the data that had been obtained and then sorted each data according to focus and then made conclusions on each of the findings of the focus. After the data analysis process is followed by an examination of the validity of information findings using triangulation techniques (source, method/ technique, and time), member checking, extension of observation time, and adequacy of reference material.

\section{RESUlts AND DisCUSSION}

The vision formulated in 2018 by this school is "superior in quality processes to realize moral quality, output quality, and outcome quality." The process of formulating the vision carried out by the school principal includes: 1) gathering all teachers and staff to formulate the school's vision; 2) conduct a SWOT analysis of schools; 3) accommodate suggestions, input, and references as material for consideration; 4) formulate a vision that can take root and will become a new culture of schools with the involvement of all teachers and staff, based on school conditions and overhaul the vision before, 5) formed a small team of five people.

\section{A. Formulation of the Vision Implemented by the Principal}

As a leader, the head of Surabaya Health Vocational School has a view and dreams will be taken to where the school is headed. This view will affect the changes in the institution along with the elements and components of the school. In order to be able to bring a positive influence, these views are arranged through a formulation of the school's vision. According to Theodore Hesburgh quoted by Larry F. Johnston in his book entitled "Visionary Leaders" he said: "The very essence of leadership is you have to have a vision. It's got to be a vision you can articulate clearly and forcibly on every occasion. You won't blow uncertain trumpet. Indirectly, the nature of leadership is that you must have a vision.

The findings related to the formulation of the vision carried out by the principal were several stages. Starting from the principal, the whole teacher and staff gather in order to form a shared vision. This is done because school changes are carried out jointly based on a vision formulated together. This vision will later be used as a guideline in every action by every school citizen. The vision to be compiled must form a school culture in line with expectations in the future.

By involving all teachers and staff, the hope is that it can simplify the process of analyzing school conditions to be coordinated with small teams that have been formed. The formation of this little team that produced the school's vision with all competitions was conducted.

\section{B. The Shared Vision Process carried out by the Principal}

The principal conducts shared vision to achieve the goals to be achieved in the future. In the shared vision process the school principal socializes, communicates, and directs all school components to jointly support and contribute to achieving the vision. [4] that principals are those who know a lot of their duties and those who determine the rhythm for their school ". Through this process the school will get commitment from the school community in the form of implementing its value, this commitment is an initial mental investment that will be formed with an effort to achieve a school vision through a shared vision process carried out by the school principal with all school components. The principal gives messages to all school components through the strategies implemented to form characterized. principals have the most basic role in communicating the values, behaviors, and expectations of all school people which are manifested in the form of actions such as speech, messages, and non-verbal behavior .

Some of the strategies carried out by the principal by socializing, memorizing, implementing, reminding, evaluating and evaluating, as well as providing reward and punishment. The school's vision is owned by school residents and carried out by school residents. This is indicated by the realization of competent graduates and no one who adores. The success of the school is one form of shared vision to the school component, so they are moved to participate and contribute to the quality of the process in the school.

In this case the principal provides a wide opportunity for students, teachers and staff to contribute in improving the quality of the process by conducting learning innovations that will have a positive impact on realizing the school's vision.

Communication and interaction is done as an effort to improve communication in the shared vision process, namely through meetings and face to face. The headmaster sets an example in every action and behavior. The example given is the translation of the vision into the form described above. Telada is done by the principal as a leader, an example by the teacher and staff to the students. This is so that the vision can be understood by all school people. In accordance with the opinion conveyed [5]. that a leader is someone who should look far ahead, someone who presents a renewal with his thoughts followed by his men.

Based on the results of the research with the theoretical basis above, it is concluded that the shared vision process is interpreted in two meanings, namely a shared vision and the translation of vision. These two meanings are interrelated, because in their application both are a series of processes. The Shared Vision process set by the head of the Surabaya Health Vocational School includes: a) socialization; b) memorized by all school members; c) Implementation; d) remind; e assessment.

\section{The process of implementing the vision carried out by the principal}

The need for smiles, greetings, greetings, discipline, orderly, and courtesy is the application of the value of vision to realize moral quality in Surabaya Health Vocational School. This action is carried out by all school members.

Learning activities with the availability of representative facilities and infrastructure, good service is a value of superior vision in the quality process to realize quality output, so as to produce superior products and have competitiveness with other schools. 
The principal collaborates with the Business World and the Industrial World as partners in improving the competency of students' skills in accordance with the work environment, with guidance by competent practitioners. This is as the application of superior vision values in the quality process to realize outcame quality.

Every job is carried out with full responsibility so that professional and caring values can be implemented properly by each class action research. [6] This is in line with what was conveyed that there are 8 things that need to be considered in the success of character education in schools, namely: 1) understanding the nature of character education; 2) properly disseminate; 3) creating a conducive environment; 4) developing adequate learning facilities and resources; 5) discipline students; 6) choose a trustworthy school principal; 7) realizing teachers that can be written and imitated; 8) involving all school members in the success of character education.

The implementation of this vision is inseparable from the leadership skills of the principal until now Surabaya Health Vocational School have a professional and caring brand. This is a positive energy from the development of the implementation of vision values that have been shared with the school community, so that school change will be very good. As the opinion that the principal as part of the education staff has a strategic position. Namely as a manager who is responsible for utilizing all school resources to achieve goals, and as a supervisor who is responsible for improving and determining the quality of teacher learning.

\section{The Approach Conducted by the Principal in Visionary Leadership Implementation To Develop Student Character}

In observations in the field, researchers found several approaches carried out by the principal, namely through the culture of spiritual morning which was carried out before starting the first lesson. In this activity it contains the reading of the initial prayer of the lesson, the delivery of information and the giving of motivation through the central audio in the Administration room. The purpose of the spiritual morning in addition to disciplining teachers and students, namely giving motivation also providing examples and good service to students by arriving early. In accordance with the opinion that schools help parents work on good habits as well as immersing good manners and giving lessons in ethics, religion, aesthetic, justifying right or wrong and so on .

Specific policies related to students applied by principals are that students must arrive on time, female students are not permitted to use make up, students must collect handheld communication devices in the Counseling Guidance room before the lesson begins. The school also wants to provide maximum service to students. The principal is also modeling by giving examples and other good attitudes and behaviors as a form of leadership. In habituation, daily activities are found to be controlling by the principal when character building. that character education is not only related to the problem rightwrong, but how to instill habits about things that are good in life, so that students have awareness, high understanding, and concern and commitment to implementing policies in everyday life.

\section{E. The Character of the Participants Involved in the Implementation of Principal's Visionary Leadership}

The character of the students developed by the head of the Surabaya Health Vocational School began with the desire expressed in the school's vision. Based on that vision the principal and the teacher and staff translate into activities that can develop the character or values of the vision. By translating into simpler school activities students will practice the values developed by the school and indirectly become value education. The main values developed by the head of the seklah include religious formation, discipline, responsibility. Of the three values found in the field, among others, in sholah dhuhur and ashar activities in congregation, tadarus short letters, distribution of Person in Charge (PIC), gropekan, and so on. This is in accordance with the opinion conveyed by Amri, S., et al. that the character of education must be included in the daily routine climate of the school. Discipline values in Surabaya Health Vocational School are displayed through timely attendance, comply with established policies and are willing to accept the consequences if they violate. looks at the punishment given every day to students who violate this in line with the expression of Aristotle character closely related to habits or habits that are constantly practiced or practiced.The value of religious coaching in schools is shown through dhuhur prayer activities and Ashar in congregation as well as a short letter, accompanied by the headmaster.

\section{CONCLUSION}

The objectives of this study are:

1) Formulate a vision by gathering all teachers and school staff to form a shared vision. After the principal, together with all classroom action research the conditions of the school were carried out at that time. The principal then accommodates suggestions for consideration. Vision is organized through the formation of small teams; 2) The process of shared vision is carried out through the dissemination of all components of the community, memorized by all school components, implemented into behavior and each school activity, the principal reminds employees through reprimand and example, the implementation of the school principal evaluates and rewards and punishes all components; 3) The implementation of the vision is carried out through: (a) Smiles, greetings, greetings, discipline, orderly, and manners; (b) quality learning processes supported by facilities and infrastructure that are competent representatives and teachers; (c) every work is carried out with full responsibility; (d) collaboration with schools with the World of Business or Industry in improving student competence; 4) There is a spiritual approach led in the morning for the implementation of the school vision carried out by principals, dhuhur and ashar prayer activities in congregations and tadarus short letters, applying industrial culture with $5 \mathrm{~S}$ to realize superior quality. Student characters are developed by the principal including: religion, discipline, and responsibility. These things arise in the activity: Prayer in congregation, short tadarus letter, gopekan movement, Person in Charge (PIC) distribution and others. 


\section{REFERENCES}

[1] S. R. Covey, "Principle-Centered Leadership Kepemimpinan yang Berprinsip," Jakarta Bin. Aksara, 1997.

[2] R. M. Stogdill and A. E. Coons, "Leader behavior: Its description and measurement.," 1957.

[3] J. M. Lipham, R. Rankin, and J. A. Hoeh, The principalship: Concepts, competencies, and cases. Addison-Wesley Longman Limited, 1985.

[4] I. I. Gunawan, "The Application of Instructional Management
Based Lesson Study and its Impact with Student Learning Achievement," in 2nd International Conference on Educational Management and Administration (CoEMA 2017), 2017.

[5] E. Mulyasa, "Improved Quality Management Based Learning for Preparing the Character of Graduates in Response to Globalization Era," Int. J. Educ. Res., vol. 4, no. 11, pp. 385-393, 2016.

[6] W. Perkins and B. Perkins, Awaken the leader within: How the wisdom of Jesus can unleash your potential. Zondervan, 2002. 